DOI 10.4467/2543733XSSB.21.007.13800

\author{
JACEK WOJNICKI
}

Katedra Systemów Politycznych

Uniwersytet Warszawski

\title{
MODELE PRZEMIAN POLITYCZNYCH W REGIONIE EUROPY ŚRODKOWEJ I WSCHODNIEJ
}

\author{
Models of Political Changes in the Region of Central and Eastern Europe
}

Summary

The article discusses the issues of transformation processes in Central and Eastern Europe. The analysis took many factors into account: geographical, historical, political, political, social and economic. Internal and external premises decided about the course of political and political changes initiated at the turn of the 1980s and 1990s. Classical political theories about the Transition to democracy were included. A research hypothesis was put forward that the traditions of democratic political institutions have a positive impact on the pace and extent of consolidation of the democratic system.

Keywords: transition, transformation, democratization, Central and Eastern Europe, political pluralism

Słowa kluczowe: tranzycja, transformacja, demokratyzacja, Europa Środkowa i Wschodnia, pluralizm polityczny

Artykuł poświęcony jest próbie ukazania modeli przemian politycznych w państwach regionu Europy Środkowej i Wschodniej. Cezura czasowa wybrana dla niniejszej analizy obejmuje okres po 1989 roku, choć w części omawianych państw przesłanki przemian społeczno-politycznych były już zauważalne w latach osiemdziesiątych (casus Polski, Węgier czy ZSRR). Analiza obejmuje państwa stanowiące w latach osiemdziesiątych tzw. radziecką strefę wpływów w Europie, ale również poszerzoną o dwa państwa socjalistyczne, które wypracowały - odmiennymi metodami - znaczną niezależność od polityków radzieckich (casus Jugosławii i Albanii). Hipoteza zasadnicza artykułu brzmi - tradycja ustrojowa (a szerzej państwowa) wpływa znacząco na przebieg procesów przemian politycznych (w tym ustrojowych) w omawianym regionie; oraz że w ramach analizowanych przypadków 
można wypracować konkretne modele teoretyczne zachodzących transformacji ${ }^{1}$. Można powyższą hipotezę umieścić w kontekście teoretycznym instytucjonalizmu historycznego.

Na wstępie należy odnieść się do zagadnień teoretycznych. Przemiany polityczne w Europie - zachodzące w ciągu ostatnich 30 lat - definiowane były przez przedstawicieli politologii najczęściej jako „tranzycje” lub „transformacje”. Najpierw należy rozstrzygnąć kwestię, czy oba terminy możemy traktować jako synonimiczne, czy wręcz przeciwnie - zachodzą między nimi dyferencje. Osobiście stoję na stanowisku, iż oba terminy nie stanowią prostych zamienników. „Tranzycja” jest bowiem zazwyczaj definiowana jako okres przejścia od systemu niedemokratycznego do form systemu demokratycznego. Tak zakładała najbardziej optymistyczna definicja przyjmowana w początkach lat dziewięćdziesiątych, gdy procesy transformacyjne postrzegano linearnie. Natomiast „transformacja”, pochodząca z nauk biologicznych, jest treściowo pojemniejsza, obejmuje bowiem całokształt przeobrażeń wewnętrznych, nie przesądzając o efektach (w tym politycznych, społecznych, gospodarczych czy ustrojowych) zachodzących przemian².

Zbigniew Brzeziński (amerykański politolog polskiego pochodzenia) opracował pod koniec lat osiemdziesiątych, uwzględniając przemiany społeczno-polityczne i międzynarodowe uwarunkowania, cztery modele zmian polityczno-ustrojowych w państwach Europy Środkowej i Wschodniej. Wspomniane modele obejmowały następujące elementy: komunistyczny totalitaryzm, komunistyczny autorytaryzm, postkomunistyczny nacjonalizm oraz postkomunistyczny autorytaryzm ${ }^{3}$. W nawiązaniu do powyższego modelu wydarzeń polski historyk w USA Marek Chodakiewicz wymienia trzy ideologie stykające się w najnowszej historii omawianego regionu: 1) postkomunizm; 2) nacjonalizm oraz 3) demokrację - decydujące o przebiegu procesu zachodzących przemian ${ }^{4}$.

Region Europy Środkowej i Wschodniej może być definiowany na różnorodne sposoby; przesłanki uzasadniające dokonany wybór mają charakter historyczny, polityczny, ustrojowy, społeczny oraz gospodarczy. Kryterium geograficzne posługuje się wyróżnikiem obszaru położonego na wschód od państwa niemieckiego, na zachód od państwa rosyjskiego (czy jego zróżnicowanych form historyczno-ustrojowych typu Związku Radzieckiego), a na północ od Grecji i Turcji (południowy skrawek Półwyspu Bałkańskiego). Z kolei uzasadnienie polityczno-historyczne pozwala na wyróżnienie regionu $\mathrm{ABC}$ - a jego nazwa pochodzi od trzech mórz: Adriatyku, Bałtyku i Morza Czarnego 5 .

${ }^{1}$ Zob. Transformacja, elity, spoleczeństwo, (red.) M. Jarosz, Warszawa 2007; J. Kofman, W. Roszkowski, Transformacja i postkomunizm, Warszawa 1999; Transformacja, integracja, globalizacja, (red.) S. Miklaszewski, Kraków 2003; J. Winiecki, Transformacja postkomunistyczna: studium przypadku zmian, Warszawa 2012; Transformacja systemowa w krajach Europy Środkowej, Wschodniej i Poludniowej 1989-2002: wybrane problemy, (red.) T. Godlewski, A. Koseski, K. A. Wojtaszczyk, Bydgoszcz-Pułtusk 2003; H. Chołaj, Transformacja systemowa w Polsce: szkice teoretyczne, Lublin 1998.

${ }^{2}$ Zob. Transformacja systemowa w Polsce: wybrane aspekty, (red.) K. Labędź, Kraków 2012; Transformacja systemowa w Polsce i krajach postkomunistycznych, (red.) M. Chałubiński, Pułtusk 2006; Transformacja ustrojowa państw Europy Środkowej i Wschodniej, (red.) E. Zieliński, Warszawa 1996.

${ }^{3}$ Zob. Z. Brzeziński, Wielkie bankructwo. Narodziny i śmierć komunizmu w XX wieku, Paryż 1990, s. 289 (pierwodruk: Z. Brzeziński, Grand Failure: The Birth and Death of Communism in the Twentieth Century, Prentice Hall \& IBD; 1st edition 1989).

${ }^{4}$ Zob. M. Chodakiewicz, Międzymorze, Warszawa 2016 (pierwodruk: Intermarium: the land between the Black and Baltic Seas, New Brunswick: Transaction Publishers, 2012).

${ }^{5}$ Zob. Europa Środkowa: wspólnota czy zbiorowość?, (red.) R. Zenderowski, Wrocław 2004; Europa Środkowa jako przestrzeń spotkania: na szlakach tradycji kultury, (red.) K. Święcicki, Gniezno 2012; Europa 
Kilka elementów pozwala mówić o wspomnianym obszarze jako regionie wspólnym i jednolitym pod względem historycznym, politycznym czy też ustrojowym. Jakie są to wspólne elementy?

Po pierwsze: przebieg procesu państwowotwórczego (na Bałkanach nawet możemy go określić jako narodowotwórczy) w połowie XIX i na początku XX wieku. Jak spojrzymy na mapy polityczne Starego Kontynentu w połowie XIX stulecia, a następnie w 1912 roku (zatem tuż przed wybuchem pierwszej wojny światowej), to znajdziemy na nich w pierwszym przypadku tylko cztery ogromne państwa rozpościerające się na omawianych obszarach Europy Środkowej i Wschodniej - Cesarstwo Niemieckie, wcześniej Królestwo Pruskie na zachodzie, Imperium Rosyjskie na wschodnich połaciach regionu, Cesarstwo Austro-Węgierskie w centralnej części oraz Imperium Porty na południowym obszarze. Druga mapa - ukazująca przemiany polityczne po około 50 latach, tuż przed wybuchem działań wojennych w lipcu 1914 roku - pozwala dostrzec największe zmiany na odcinku południowym: Turcja wycofuje się z kontynentu, powstają nowe państwa (Rumunia w 1859 roku, Albania w 1912 roku), bądź ulegają odtworzeniu te, które zanikły pod wpływem militarnych działań tureckich w XIV i XV wieku: Serbia, Czarnogóra oraz Bułgaria na mocy traktatu berlińskiego z 1878 roku. Zmiany w części wschodniej i zachodniej omawianego obszaru stanowić będą bezpośredni (a w najgorszym wypadku pośredni) rezultat rozpadu wewnętrznego pozostałych trzech imperiów. Po 1918 roku powstaną nowe państwa - Czechosłowacja, Królestwo SHS (od 1929 roku Jugosławia), odrodzą się państwowe byty - Polska, trzy państwa bałtyckie o dość zróżnicowanej tradycji ustrojowej. Obecną postać geograficzną osiągnie państwo węgierskie po zerwaniu więzów z Wiedniem i utracie części ziem na rzecz sąsiadów - Jugosławii, Rumunii, Czechosłowacji czy Ukrainy ${ }^{6}$.

Po drugie: nowo powstałe organizmy państwowe (czy też takie, które odrodziły wówczas swój byt niepodległy) poszukiwały w latach dwudziestych optymalnego modelu ustrojowego. Uznano dość powszechnie, iż modelem zapewniającym demokratyczny ustrój będzie forma parlamentarna, wzorowana przede wszystkim na instytucjach polityczno-ustrojowych Trzeciej Republiki Francuskiej. Dość porównać ustawy konstytucyjne uchwalane na początku ówczesnej dekady w analizowanych państwach - w Czechosłowacji w 1920 roku, w Polsce i Królestwie SHS w 1921 roku, w Rumunii w roku 1923, czy konstytucje Litwy, Łotwy i Estonii. Uwzględniając tradycje państwowe i ustrojowe, nawiązywano do modelu parlamentarno-gabinetowego, ze wszystkimi jego zaletami i wadami. Do zalet wspomnianego modelu zaliczano demokratyczne wybory, brak klauzul zaporowych dla list partyjnych w elekcjach parlamentarnych, podział władz (choć nie jego równowagę, co się zemści po pewnym czasie), pluralistyczną scenę polityczną, uprawnienia prawotwórcze skupione w legislatywie, dość szerokie uprawnienia dla samorządów lokalnych.

Środkowa i Wschodnia wXX wieku: studia ofiarowane Wiesławowi Balcerkowi $w 70$ rocznicę urodzin, (red.) A. Koryn, P. Łossowski, Warszawa-Łowicz 2004; Europa Środkowo-Wschodnia wobec wyzwań integracyjnych, (red.) A. Stępień-Kuczyńska, Łódź 2003.

${ }^{6}$ Zob. Europa Środkowa i Wschodnia w 19 i 20 wieku, (red.) E. Wiśniewski, Łódź 2005; J. Kłoczowski, Europa Środkowowschodnia w historiografii krajów regionu, Lublin 1993; W. Roszkowski, East Central Europe. A Concise History, Warsaw 2015; Historia Europy Środkowowschodniej, tom I, (red.) J. Kłoczowski, Lublin 2000; P. S. Wandycz, Cena wolności. Historia Europy Środkowowschodniej od średniowiecza do wspótczesności, Kraków 2003 oraz M. Sobolewski, Od drugiego cesarstwa do piqtej republiki: z dziejów politycznych Francji 1870-1958, Warszawa 1963. 
Model parlamentarny nie zapewnił jednakże stabilności Trzeciej Republice, czego starano się jednakże nie dostrzegać przy recepcji francuskich rozwiązań polityczno-ustrojowych w Europie Środkowej i Wschodniej. Zastosowanie instytucji parlamentarnych w nowych państwach, pozbawionych (na ogół) własnych tradycji parlamentarnych i mających niestabilne sceny partyjne - prowadziło bezpośrednio do zbytniej fragmentaryzacji ciał ustawodawczych, częstych kryzysów parlamentarnych i niestabilnych rządów. Symbolem tej niestabilności systemu parlamentarnego niech będzie 14 gabinetów urzędujących w Drugiej Rzeczypospolitej w okresie od listopada 1918 do maja 1926 roku. Gdy dodamy brak umiejętności współpracy ugrupowań politycznych i niską kulturę polityczną, szczególnie w warunkach wieloelementowej mozaiki etnicznej, wówczas konsekwencje kryzysów parlamentarnych urastają do paraliżu państwa z powodu rozległych i częstych kryzysów politycznych, antagonizujących społeczeństwa wschodniej i środkowej Europy. W większości państw występowała dodatkowo tradycja silnej władzy jednostki, która była symbolizowana przez monarchów, dowódców wojskowych, jak J. Piłsudski czy M. Horthy. Formuła parlamentarna nie była zatem dość wygodnie „skrojona” na organizmy państwowe omawianego regionu Starego Kontynentu?

Po trzecie: konsekwencją niestabilności politycznej oraz nawarstwiającego się kryzysu gospodarczego były - w warunkach niestabilności etnicznej - narastające tendencje autorytarne. Stanowiły one poniekąd odpowiedź na nurty płynące zarówno z zachodniej części kontynentu - włoski faszyzm, niemiecki hitleryzm, jak również wschodni komunizm w wykonaniu W. Lenina jako twórcy państwa radzieckiego, czy jego następcy J. Stalina. Forma powstających modeli autorytarnych była dość zróżnicowana, miały na ogół charakter konserwatywny (sanacja w Polsce, hortyzm na Węgrzech). Formuły najbliższe faszyzmowi włoskiemu osiągnęła dyktatura rumuńska po 1938 roku, choć pewne elementy można również dostrzec w polityce gabinetu węgierskiego kierowanego przez Gy. Gőmbősa w latach trzydziestych. Dyktatura królewska w Jugosławii, ustanowiona w styczniu 1929 roku przez Aleksandra I - miała na sztandarach hasła ocalenia wspólnego bytu państwa Słowiańszczyzny Południowej, naznaczonej rosnącymi antagonizmami chorwacko-serbskimi, czego najdramatyczniejszym wyrazem były strzały w Skupsztinie w czerwcu 1928 roku, wymierzone do chorwackich deputowanych. Najdłużej system demokratyczny przetrwał w Pierwszej Republice Czechosłowackiej - do jesieni 1938 roku. Dyktatorzy pozostawiali pewien margines swobody politycznej, czego dowodziły - manipulowane jednakże, wybory do parlamentów: w Polsce po 1926 roku, w Jugosławii po zamachu styczniowym czy na Węgrzech w latach dwudziestych i trzydziestych. Formy autorytarne niemniej ewoluowały wewnętrznie, czego symbolem może być polska konstytucja kwietniowa z 1935 roku oraz wyeliminowanie opozycji parlamentarnej zarówno z ław sejmowych, jak i senackich. Podobnie jak rozwiązanie ugrupowań politycznych przez dyktaturę królewską w Rumunii w marcu 1938 roku czy zniesienie pluralizmu politycznego w przypadku albańskim przez dyktaturę Zogu w okresie po 1928 roku. Zróżnicowanym problemem jest również kwestia współpracy militarnej oraz politycznej z państwami faszystowskimi,

${ }^{7}$ Zob. S. Starzyński, Współczesny ustrój prawno-polityczny Polski i innych państw stowiańskich, Lwów 1928 [reprint z 2010]; W. Komarnicki, Polskie prawo polityczne, Warszawa 1922 [reprint z 2008]; Nowe konstytucje, (red.) J. Makowski, Warszawa 1925; A. Gwiżdż, Burżuazyjno-obszarnicza konstytucja z 1921 roku w praktyce, Warszawa 1956; A. Ajnenkiel, Parlamentaryzm II Rzeczypospolitej, Warszawa 1975. 
symbolizowanymi przez oś Berlin-Rzym-Tokio, w latach trzydziestych i czterdziestych. Nie stanowi ona jednakże kwestii analiz w niniejszym przypadku, należy ją tylko zasygnalizować dla porządku badań sytuacji społeczno-politycznej w omawianym regionie Starego Kontynentu ${ }^{8}$.

Po czwarte: należy wspomnieć o konsekwencjach społeczno-politycznych i gospodarczych zaliczenia owego regionu do tzw. radzieckiej strefy wpływów w następstwie działań militarnych podczas drugiej wojny światowej oraz uzgodnień polityków wielkich mocarstw w Jałcie i Poczdamie (zima i lato 1945 roku). Stosunki z państwem radzieckim i odniesienie do społeczeństwa (czy też raczej społeczeństw) ZSRR należały do dość zróżnicowanych. Najwięcej ciepłych uczuć budzili Rosjanie w Czechosłowacji (jako efekt ideologii słowianofilstwa - z Rosją na czele) oraz w Bułgarii (jako sentyment do narodu rosyjskiego postrzeganego jako aliant $w$ potyczkach $z$ Turcją oraz podobieństwa religii i języka). $W$ mniejszym stopniu również w państwie jugosłowiańskim - przede wszystkim u prawosławnych Serbów i Czarnogórców. W Polsce, Rumunii oraz na Węgrzech Rosjanie byli traktowani raczej jako odwieczny rywal (by nie powiedzieć wróg państwa i narodu), na równi z zagrożeniem niemieckim, a czasami nawet wyprzedzając zagrożenie Drang nach Osten. $\mathrm{W}$ omawianych trzech państwach występowały spory terytorialne (i w rezultacie graniczne) z ZSRR (Kresy Wschodnie w przypadku polskim, Besarabia w przypadku rumuńskim, pogranicze węgiersko-ukraińskie z liczną ludnością madziarska). Specyficzną sytuację stanowiła radziecka strefa okupacyjna Niemiec, przyznana przez wielką czwórkę jako rekompensata za wysiłek zbrojny ZSRR i poniesione straty gospodarcze, przekształcona w październiku 1949 w odrębne państwo niemieckie wzorowane na ustrojowym modelu radzieckim. Zwrócić uwagę należy również na endo- oraz egzogenne przesłanki ustanowienia władzy komunistycznej oraz kształtowania nowego modelu państwa „,demokracji ludowej”. Pod względem społeczno-gospodarczym omawiany region był dość zróżnicowany. Uprzemysłowione i rozwinięte ziemie niemieckie czy czeskie stanowiły podstawę przemysłowo-rolniczego modelu państwa $\mathrm{w}$ omawianych dwóch przypadkach (ponad połowa PKB była tam wytwarzana z przemysłowej części sektora gospodarczego). Były to najbogatsze i najbardziej rozwinięte gospodarczo państwa demokracji ludowej. Podobnie kształtowała się struktura gospodarcza $\mathrm{w}$ dwóch najbogatszych republikach jugosłowiańskich - Słowenii oraz Chorwacji. Z kolei Polska i Wegry stanowiły model pośredni przemysłowo-rolniczy, gdzie przemysł rozwijał się już w warunkach władzy ludowej, ale ważnym sektorem gospodarczym nadal pozostawało rolnictwo. Należy wspomnieć o sporym uzależnieniu od kapitału zagranicznego - niemieckiego, francuskiego, brytyjskiego oraz włoskiego. Trzeci model obejmuje państwa bałkańskie, o dominującej pozycji rolnictwa w sektorach gospodarczych (biedniejsze republiki jugosłowiańskie - Bośnia i Hercegowina, Czarnogóra czy Macedonia, najbiedniejszy pozostawał okręg autonomiczny Kosowo, utworzony w ramach Serbii). Obszar ten w większości określano jako państwa peryferyjnego kapitalizmu (oprócz ziem czeskich, słoweńskich oraz wschodnich landów niemieckich). Mówiąc o sytuacji politycznej oraz popularności ugrupowań lewicy komu-

${ }^{8}$ Zob. G. Besier, K. Stokłosa, Europa dyktatur: nowa historia XX wieku, Warszawa 2009; Dyktatury w Europie Środkowo-Wschodniej, (red.) J. Żarnowski, Wrocław 1973; Przewroty i zamachy stanu. Europa 1918-1939, (red.) A. Garlicki, Warszawa 1981; J. W. Borejsza, Szkoły nienawiści: historia faszyzmów europejskich: 1919-1945, Wrocław 2000; Czas totalitaryzmu: stalinizm, faszyzm, nazizm i pokrewne systemy polityczne w XX wieku, (red.) J. Szymoniczek, E. C. Król, Warszawa 2011. 
nistycznej, należy wspomnieć, iż legalnie partie komunistyczne mogły działać przed drugą wojną światową tylko w Republice Weimarskiej i w Czechosłowacji. Politycy komunistyczni ubiegali się o mandaty poselskie i kandydowali - z sukcesem - w wyborach parlamentarnych. W pozostałych państwach ugrupowania komunistyczne były zdelegalizowane i nie ubiegały się o mandaty deputowanych (casus Polski, Węgier, Bułgarii czy Jugosławii). Dodatkowo w państwach bałkańskich partie komunistyczne były rachityczne i słabo zorganizowane, przewaga rolnictwa oraz niski poziom uprzemysłowienia powodowały, iż nie miały one naturalnych grup sympatyków, wyborców oraz zwolenników. Skrajny przypadek stanowiła Albania, gdzie ugrupowanie komunistyczne współtworzyli politycy jugosłowiańscy po 1944 roku. Podobnie słabe struktury komunistyczne występowały w przedwojennej Rumunii. Siła i atrakcyjność ugrupowań komunistycznych w omawianym regionie wynikała głównie z przesłanek zewnętrznych, jako polityczne przedłużenie militarnej władzy Armii Czerwonej. Po zakończeniu działań wojennych poszczególne ugrupowania komunistyczne budowały struktury organizacyjne i przystępowały do działań wzmacniających i konsolidujących władzę polityczną w państwie. Do wspomnianych ugrupowań należy zaliczyć: Polską Partię Robotniczą (PPR), Komunistyczną Partię Czechosłowacji (KSČ), Komunistyczną Partię Węgier (MKP), Bułgarską Partię Robotniczą (BRP), Komunistyczną Partię Rumunii (CPR), Komunistyczną Partię Jugosławii (KPJ) oraz Komunistyczną Partię Albanii (KPA). Symptomatyczne jest dokonywanie zmian ugrupowań na robotnicze w kolejnych latach, po wchłonięciu części polityków socjaldemokratycznych oraz socjalistycznych - Albańska Partia Pracy, Rumuńska Partia Robotnicza, Węgierska Partia Pracujących (1948-1956), a po 1956 - Weegierska Socjalistyczna Partia Robotnicza czy Polska Zjednoczona Partia Robotnicza. Zmiana szyldu miała świadczyć, iż celem politycznym i ideologicznym wspomnianych ugrupowań nie jest państwo komunistyczne, tylko kształtowanie ustroju demokracji ludowej (w latach czterdziestych i pięćdziesiątych), a w następnym etapie (od lat sześćdziesiątych) państwa socjalistycznego. Miało to świadczyć o pewnym samoograniczeniu tendencji rewolucyjnych $\mathrm{w}$ funkcjonowaniu modelu zarówno systemu społeczno-politycznego, jak i gospodarczego. Wspomnieć należy również o wewnętrznym zapleczu nowego państwa w przypadku jugosłowiańskim i albańskim. W obu przypadkach pomoc militarna ze strony Armii Czerwonej odgrywała marginalne znaczenie (w przypad$\mathrm{ku}$ albańskim praktycznie zerowe). Udział $\mathrm{w}$ walce $\mathrm{z}$ okupantem włoskim i niemieckim stanowił zasadniczy fundament działań legitymizacyjnych komunistów jugosłowiańskich skupionych wokół J. Broza-Tito. Z kolei oswobodzenie ziem albańskich zostało wsparte politycznie i militarnie przez oddziały titowskie. Stanowiło to ważny element konsolidacji ówczesnego systemu politycznego oraz zakorzenienia społecznego ugrupowań komunistycznych (czego dowodem były sukcesy wyborcze po 1990 roku zarówno w przypadku większości republik jugosłowiańskich, jak i casus postkomunistycznej Albanii) ${ }^{9}$.

Kolejną kwestią jest stabilność reżimu komunistycznego w omawianych państwach Europy Środkowej i Wschodniej. Występowanie objawów niezadowolenia społecznego

${ }^{9}$ Zob. Z. Brzeziński, Jedność i konflikty, Londyn 1964; F. Fejtő, A History of the People's Democracies. Eastern Europe Since Stalin, New York, Washington, London 1971; H. Seton-Watson, The East European revolution, Westview Press, 1985; R. Lee Wolff, The Balkans in Our Time, Cambridge, Massachusetts 1956; St. Fisher-Galati, Wspótczesna Europa Środkowo-Wschodnia. Dziedzictwo historii, Lublin 2006; Państwa komunistyczne u progu lat siedemdziesiatych, (red.) T. Rakowska-Harmston, A. Bromke, Londyn 1973; idem, Communism in Eastern Europe, (red., współaut.), Manchester University Press 1979, 1984. 
charakteryzuje kilka państw - do strajków, demonstracji czy walk zbrojnych doszło w Berlinie w czerwcu 1953 roku, w Budapeszcie i na terytorium Węgier w październiku i listopadzie 1956 roku, w Czechosłowacji wiosną i latem 1968 roku oraz w Jugosławii w 1968 roku. Najmniej stabilna sytuacja społeczno-polityczna panowała w Polsce, czego wyrazem jest kilka przełomów politycznych - czerwiec i październik 1956 roku, marzec 1968 roku, grudzień 1970, czerwiec 1976 roku oraz przełom społeczno-polityczny 1980/1981 roku. Z drugiej strony za najstabilniejsze uchodziły reżimy komunistyczne w państwach bałkańskich - w Albanii, Bułgarii czy Rumunii ${ }^{10}$.

Po piąte: wspólne doświadczenie przeobrażeń polityczno-ustrojowych w państwach regionu, począwszy od 1989 roku. Procesy transformacyjne były obserwowane i analizowane przez wielu badaczy z nauk społecznych, podstawowym zagadnieniem było znalezienie narzędzi badawczych dla opisu i analizy zmian polityczno-ustrojowych w Europie Środkowej i Wschodniej. Powstała nawet odrębna subdyscyplina w naukach społecznych (politologii, historii najnowszej, socjologii czy prawie konstytucyjnym), nazywana od przedmiotu swoich badań „tranzytologią"11. Analizując przebieg procesów transformacyjnych, należy zwrócić uwagę na kilka elementów. Po pierwsze: badacze poszukiwali podobieństw do innych procesów demokratyzacyjnych w najnowszej historii Europy (i szerzej, nie tylko procesów regionalnych, ale i procesów globalnych). Za punkt porównań i komparatystycznych analiz dobierano zazwyczaj przemiany polityczno-ustrojowe połowy lat siedemdziesiątych w państwach Europy Zachodniej. Wówczas upadły, bądź ulegały znaczącym przekształceniom, trzy dyktatury: w Portugalii, w Hiszpanii oraz w Grecji. Zakres zmian politycznych, a także charakter reżimów był jednakże odmienny od państw Europy Środkowej i Wschodniej. Należy wskazać na szerszy zakres zmian społeczno-gospodarczych, w tamtych państwach gospodarka rynkowa działała w sposób ograniczony bądź częściowo wypaczony (z wyjątkiem Hiszpanii po zmianach rynkowych przełomu lat pięćdziesiątych i sześćdziesiątych). Także geneza reżimów była endogenna, co tłumaczyło konsolidację dyktatury Franco w Hiszpanii oraz dyktatury Salazara w Portugalii (odmienny casus Grecji pod rządami „,czarnych pułkowników”) ${ }^{12}$.

Nawiązywano do klasycznych badań przejścia od systemu niedemokratycznego do systemu demokratycznego, odwołując się do teorii Morlino ${ }^{13}$. Wskazywano na etapowość przemian: od procesu inicjacji zmian, poprzez ich przebieg do fazy konsolidacyjnej (stabilizacyjnej). Badania L. Morlino odwoływały się do teoretycznych aspektów procesów

\footnotetext{
${ }^{10}$ Zob. J. Tomaszewski, Europa Środkowo-Wschodnia 1944-1968: powstanie, ewolucja i kryzys realnego socjalizmu, Warszawa 1992; W. Roszkowski, Pótwiecze: historia polityczna świata, Warszawa 2005; J. Holzer, Komunizm w Europie: dzieje ruchu i systemu władzy, Warszawa 2000; A. Biagini, F. Guida, Pół wieku realnego socjalizmu: Europa Środkowowschodnia od II wojny światowej do upadku rzq̨ów komunistycznych, Rzeszów 1998; Ł. Kamiński, A. Malkiewicz, K. Ruchniewicz, Opór społeczny w Europie Środkowej w latach 1948-1953 na przykładzie Polski, NRD i Czechostowacji: wstęny raport z badań, Wrocław 2004; A. Dudek, T. Marszałkowski, Walki uliczne w PRL 1956-1989, Kraków 1999.

${ }^{11}$ Zob. Demokratyzacja w III Rzeczypospolitej, (red.) A. Antoszewski, Wrocław 2002.

${ }^{12}$ Zob. Demokracje Europy Środkowo-Wschodniej w perspektywie porównawczej, (red.) A. Antoszewski, R. Herbut, Wrocław 1997; J. Holzer, Europa zimnej wojny, Kraków-Warszawa 2012; Reform and transformation in Eastern Europe, (red.) W. Łukowski, K. A. Wojtaszczyk, Warsaw 1996; J. Wojnicki, Trudna droga do demokracji. Europa Środkowo-Wschodnia po 1989 roku, Warszawa 2002; A. Przeworski, Democracy and the Market; Political and Economic Reforms in Eastern Europe and Latin America, Cambridge University Press, New York 1991.

${ }^{13}$ Zob. L. Morlino, Democratic Establishment: A Dimensional Analysis, [in:] Comparing New Democracies. Transition and Consolidation in Mediterranean Europe in the Southern cone, (ed.) E. Baloyra, London 1987.
} 
demokratyzacyjnych, bazowano na kilkudziesięciu państwach z całego świata z ostatnich kilkudziesięciu lat najnowszej historii powszechnej. Ich przydatność przy analizie zmian w regionie Europy Środkowej oraz Wschodniej okazała się ograniczona, ze względu na specyfikę regionu oraz zakres zmian wewnętrznych.

Nawiązaniem do powyższej teorii były podjęte przez amerykańskiego politologa Samuela Huntingtona próby wpisania zmian transformacyjnych w omawianym regionie w tzw. „trzecią falę demokratyzacji” " ${ }^{14}$. S. Huntington analizował zmiany demokratyzacyjne, począwszy od tzw. rewolucji goździków w Portugalii w kwietniu 1974 roku. Dostrzegał wspólne cechy procesów w różnych regionach świata. W kontekście zjawisk globalnych analizował również zmiany systemowe w państwach postkomunistycznych. Rozwinięciem wspomnianej hipotezy była koncepcja Francisa Fukuyamy odnosząca się do końca wieku ideologii, po uprzednim triumfie - jak zakładano - demokracji liberalnej nad innymi niedemokratycznymi czy mniej demokratycznymi formami ustrojowymi. Wizja powyższa okazała się zbytnio optymistyczna, zakładała bowiem linearny przebieg procesów transformacyjnych ${ }^{15}$. Alternatywny scenariusz wydarzeń przewidywał zderzenie się ze sobą konkurencyjnych, a po części wrogich cywilizacji. Amerykański politolog S. Huntington zaliczył do wspomnianych cywilizacji następujące: afrykańską, buddyjską, chińską, hinduistyczna, islamską, latynoska, japońską, prawosławną oraz zachodnią. S. Huntington akcentował, że po 1989 roku (symboliczna data końca tzw. zimnej wojny) może dochodzić do poważnych konfliktów pomiędzy poszczególnymi cywilizacjami. Dowodził, że w okresie po zakończeniu zimnej wojny, kiedy to przyczyną konfliktów były spory ideologiczne, na pierwsze miejsce powróciły spory religijno-kulturowe. Uważał on jednocześnie, że cywilizacja zachodnia systematycznie traciła swoje wpływy we współczesnym świecie. W celu zapobieżenia jej trwałej marginalizacji powinno dojść do ściślejszej kooperacji dwóch najważniejszych ogniw tej cywilizacji - Europy i Stanów Zjednoczonych ${ }^{16}$.

Analizując zachodzące przemiany polityczno-ustrojowe (ale również społeczno-gospodarcze), należy wskazać na zróżnicowane płaszczyzny zachodzących procesów transformacyjnych. Zaliczano do nich: kwestie urynkowienia (zmian w sektorze społeczno-gospodarczym), modernizacji państwa i jego instytucji, tworzenia państw narodowych, procesów europeizacji czy „końca historii” wedle cytowanej powyżej teorii Francisa Fukuyamy. Teorie modernizacyjne szczególnie popularne były w państwach postradzieckich (Federacja Rosyjska, Białoruś) oraz bałkańskich (w tym postjugosłowiańskich). Akcentowanie znaczenia modernizacji, np. w wypowiedziach liderów Rosji czy Białorusi, przesuwa znaczenie innych elementów związanych z przemianami systemów politycznych (w kierunku demokratyzacji) czy gospodarki (w kierunku zmian wolnorynkowych) ${ }^{17}$. Kwestia kształtowania nowych organizmów państwowych była pierwszym bezpośrednim efektem

${ }^{14}$ Zob. S. Huntington, Trzecia fala demokratyzacji, Warszawa 1995 (pierwodruk: The Third Wave. Democratization in the Late Twentieth Century, 1991).

${ }^{15}$ Zob. F. Fukuyama, Koniec historii, Poznań 1996 (pierwodruk: Koniec historii?, [w:] Czy koniec historii? Konfrontacje 13, New York, Warszawa 1991, Idee, Wydawnictwo Pomost, s. 7-36 (tłumaczenie eseju z „The National Interest", nr 16, lato 1989, pp. 3-18).

${ }^{16}$ Zob. S. Huntington, Zderzenie cywilizacji i nowy ksztalt ładu światowego, Warszawa 1997 (pierwodruk: w The Clash of Civilizations?, „Foreign Affairs”, lato 1993, vol. 72, pp. 22-49.

${ }^{17}$ Zob. Modernizacja w Rosji, ,Studia Politologiczne”, 2016, vol. 40; Bariery modernizacji Rosji, (red.) S. Bieleń, A. Skrzypek, Warszawa 2014; Rozpad ZSRR i jego konsekwencje dla Europy i świata, (red.) J. Diec, Kraków 2011. 
przeobrażeń ustrojowych w przypadku republik jugosłowiańskich i radzieckich. Trochę inaczej proces powyższy przebiegał w przypadku federacji czechosłowackiej, gdzie najpierw przeprowadzano reformy społeczno-polityczne i gospodarcze (demokratyzacja oraz urynkowienie), a później nastąpił rozpad wspólnego państwa federalnego ${ }^{18}$.

Inny ważny aspekt przemian obejmował kwestie ich projekcji - czy mają charakter linearny, czy zakładamy występowanie stadium regresu. Początkowe opinie (szczególnie anglosaskich politologów i analityków) zakładały optymistyczne scenariusze rozszerzania się ustroju demokratycznego oraz wycofywania się tendencji autorytarnych (czy inaczej: niedemokratycznych). Wydarzenia bałkańskie oraz niekorzystne zmiany w państwach postradzieckich (w tym w Rosji po ostrzelaniu gmachu parlamentu w październiku 1993 roku) czy sfałszowanie referendum listopadowego 1996 roku na Białorusi, wzmacniającego władzę prezydenta A. Łukaszenki, ukazały krótkowzroczność kreślenia takich pozytywnych scenariuszy.

Opracowano wiele zróżnicowanych typologii zmian transformacyjnych w omawianym regionie historyczno-politycznym oraz geograficznym. Pokrótce należy się odwołać do niektórych, symbolizowanych przez badaczy: L. Holmesa, T. G. Asha, T. Rakowską-Harmstone, S. Huntingtona, A. Agh, A. Przeworskiego, J. Linza czy B. Parrot i K. Dawisha ${ }^{19}$. Z polskich badaczy problematyka transformacyjna stanowiła przedmiot analiz J. Wiatra, A. Antoszewskiego, K. A. Wojtaszczyka, W. Roszkowskiego, J. Kofmana, E. Bujwid-Kurek czy J. Staniszkis ${ }^{20}$. Klasyczne modele zmian ustrojowych zakładały trzy zasadnicze scenariusze: bazując na kryterium zaangażowania aktorów politycznych w zmianę systemu (np. elity władzy, Kościół, opozycja antykomunistyczna, wojsko i siły bezpieczeństwa), układzie sił pomiędzy elitami władzy a opozycją oraz wewnętrznym zróżnicowaniu antagonistycznych obozów politycznych (relacje między reformatorami i „twardogłowymi” w obozie władzy oraz ,umiarkowanymi” a „radykałami” z opozycji powoduje określony przebieg pierwszego etapu zmiany systemowej). Wyróżnia się zatem: transformację, przemieszczenie oraz zastapienie. Transformacja zachodzi wówczas, gdy reformom przewodzą elity rządzące, zastapienie występuje, gdy „tranzycja” inicjowana została przez opozycję, natomiast gdy reformy stanowią dzieło wspólne rządu oraz opozycji, proces został zdefiniowany jako przemieszczenie. W ocenie S. Huntingtona transformacja miała miejsce na Węgrzech, w ZSRR, Bułgarii. Przemieszczenie wystąpiło w Polsce i Czechosłowacji,

${ }^{18}$ Zob. W. Czapliński, Zmiany terytorialne w Europie Środkowej $i$ Wschodniej i ich skutki międzynarodowo-prawne: (1990-1992), Warszawa 1998; E. Mizerski, Geneza i rozpad ustroju federalnego bylych socjalistycznych państw europejskich, Toruń 1996; H. Batowski, Podstawy kryzysu jugosłowiańskiego (konflikt chorwacko-serbski): odczyt wygłoszony na zebraniu publicznym PAU w Krakowie 16 listopada 1991 roku, Kraków 1993.

${ }^{19}$ Zob. L. Holmes, Post-Communism: An Introduction, Cambridge 1997; T. G. Ash, Wiosna obywateli: Rewolucja 1989: widziana w Warszawie, Budapeszcie, Berlinie i Pradze, wyd. pol. Polonia, Londyn 1990; idem, Pomimo i wbrew-Eseje o Europie Środkowej, wyd. pol. Polonia, Londyn 1990; T. Rakowska-Harmstone, Disintegration and Re-definition of East Europe, Warsaw 1992; A. Przeworski, op. cit.; A. Agh, The politics of Central Europe, London 1998; The consolidation of democracy in East-Central Europe, ed. K. Dawisha and B. Parrott, Cambridge Univ. Press, Cambridge, New York 1997.

${ }^{20}$ Zob. J. Wiatr, Europa pokomunistyczna: przemiany państw i społeczeństw po 1989 roku, Warszawa 2006; Demokracje Europy Środkowo-Wschodniej w perspektywie porównawczej, (red.) A. Antoszewski, R. Herbut, Wrocław 1997; Transformationsprozesse in Polen: aus der Reihe - Deutschland und Polen in Europa, (ed.) K. A. Wojtaszczyk, Warschau 1993; J. Kofman, W. Roszkowski, op. cit.; E. Bujwid-Kurek, D. Mikucka-Wójtowicz, Transformacja ustroju politycznego wybranych państw Europy Środkowej i Poludniowo-Wschodniej, Kraków 2015; J. Staniszkis, Postkomunizm. Próba opisu, Gdańsk 2001. 
natomiast zastąpienie - w NRD oraz Rumunii. Jednakże można wysuwać poważne zastrzeżenia do takiego zakwalifikowania modelów tranzycyjnych w poszczególnych państwach postkomunistycznych, gdyż należy uwzględniać szersze przesłanki społeczno-polityczne, gospodarcze, etniczne czy historyczne zmian politycznych w poszczególnych państwach Europy Środkowej i Wschodniej. Zwrócić można uwagę, iż zmiany ustrojowe w Czechosłowacji rozpoczęły się z pewnym opóźnieniem w stosunku do Polski czy Węgier, ale szybko nadrobiono dystans do liderów przemian (za jakich na początku uchodzili Polacy i Węgrzy). Z kolei w ramach federacji jugosłowiańskiej nie zdołano wypracować (można postawić pytanie, czy było to w ogóle możliwe) jednego scenariusza zmian ustrojowych, co było wyraźnym przejawem niemocy władz federalnych wobec rosnących w siłę ośrodków republikańskich (Słowenia, Chorwacja, Serbia) ${ }^{21}$. Powszechnie używano terminu „refolucja”, zaproponowanego przez anglosaskiego historyka studiów europejskich jako najtrafniejszego określenia zakresu i tempa zmian transformacyjnych w państwach postkomunistycznych. Symbolizował on jednoznacznie hybrydowe połączenie zmian rewolucyjnych oraz odgórnej reformy ${ }^{22}$.

Wedle modeli opracowanych przez Jerzego J. Wiatra ${ }^{23}$, polskiego socjologa polityki, można wyróżnić: 1) historyczny kompromis (Polska, Węgry); 2) upadek i kapitulację (NRD i Czechosłowacja); 3) kontrolowane otwarcie (Bułgaria, Rumunia, Albania) oraz 4) rozpad państwa federacyjnego (Jugosławia i ZSRR) i 5) transformację poprzez zjednoczenie (Niemcy - landy wschodnie). Wśród przesłanek przeobrażeń można wyszczególnić elementy zarówno endo-, jak i egzogenne. W wymienionym katalogu przesłanek wewnętrznych znajdujemy: czynniki gospodarcze, czynniki wewnętrzno-polityczne, inne czynniki - choćby rolę religii, Kościoła w życiu społeczno-politycznym (casus Polski, szczególnie po wyborze kard. K. Wojtyły na tron papieski). Z kolei do przesłanek zewnętrznych zalicza się powszechnie przesłanki geopolityczne oraz militarne. Socjologowie zwracają uwagę na rolę wielkich jednostek - Jana Pawła II, M. Gorbaczowa, R. Reagana, L. Wałęsy ${ }^{24}$.

Kolejnym zagadnieniem rozważanym przy obserwacji procesów transformacyjnych było namierzenie czasu zachodzących zmian. Pytanie zasadnicze brzmiało: czy można mówić o wydarzeniach równoległych (np. rozwój wydarzeń politycznych w Polsce i na Węgrzech w końcówce lat osiemdziesiątych) czy raczej o efekcie lawiny - kaskadowym nawarstwianiu wydarzeń społeczno-politycznych w kolejnych państwach (NRD w październiku 1989 roku, Czechosłowacja w listopadzie 1989 roku, Bułgaria oraz Rumunia w grudniu 1989 roku, Jugosławia w 1990 roku, Albania w 1991 roku). Również w przypadku dynamiki rozwoju sytuacji społeczno-politycznej w ramach federacji jugosłowiań-

${ }^{21}$ Zob. W. Walkiewicz, Stowiańszczyzna Południowa między przeszłościa a przyszłościa, Warszawa 2017; A. Koseski, W bałkańskim kręgu, Pułtusk-Warszawa 2013; M. Waldenberg, Rozbicie Jugosławii: od separacji Stowenii do wojny kosowskiej, Warszawa 2003.

${ }^{22}$ Zob. T. G. Ash, op. cit.

${ }^{23}$ Zob. J. Wiatr, Europa pokomunistyczna, s. 70 i nast.

${ }^{24}$ Zob. Cet étrange post-communisme. Rupture et transition en Europe central et orientale, (ed.) G. Mink, J. Ch. Szurek, Paris 1992; F. Fejtö, La fin des démocraties populaires, Le Seuil, Paris 1992; New Europe. The Impact of the First Decade, vol. 1: Trends and Prospects, (ed.) P. Dutkiewicz, T. Rakowska-Harmstone, Warsaw 2006; New Europe. The Impact of the First Decade, vol. 2: Variations on the Pattern, (ed.) P. Dutkiewicz, T. Rakowska-Harmstone, Warsaw 2006; E. Wnuk-Lipiński, Rozpad połowiczny. Szkice z socjologii transformacji ustrojowej, Warszawa 1991; idem, Demokratyczna rekonstrukcja. Z socjologii radykalnej zmiany, Warszawa 1996. 
skiej, czy w mniejszym stopniu - Związku Radzieckiego (np. w obrębie słowiańskich republik) można mówić o pewnej sekwencji wydarzeń - kaskadowe tempo wyborów parlamentarnych w poszczególnych republikach jugosłowiańskich w 1990 roku (wiosna 1990 roku w Słowenii i Chorwacji, jesień 1990 roku w Bośni i Macedonii, zima 1990 roku w Serbii i Czarnogórze $)^{25}$.

Ostatnim zagadnieniem wartym analizy jest kwestia ograniczeń czasowych procesów transformacyjnych. O ile cezura początkowa jest dość łatwa do ustalenia (i nie wzbudza poważniejszych zastrzeżeń), to cezura końcowa sprawia pewne problemy. Za początek zmian ustrojowych zazwyczaj podaje się decyzje o pluralizacji sceny politycznej, zgodę na podjęcie negocjacji strony rządowej z reprezentantami opozycji antykomunistycznej (lub demokratycznej) albo pierwsze rywalizacyjne wybory. Wspomniana elekcja często doprowadzała do alternacji władzy, casus Polski w czerwcu 1989 roku, NRD w marcu 1990 roku, Węgier na przełomie marca i kwietnia 1990 roku, Czechosłowacji w czerwcu 1990 roku. Podobnie alternacja władzy wystąpiła w dwóch republikach jugosłowiańskich - w kwietniu 1990 roku (Słowenia) oraz w maju 1990 roku (Chorwacja). Zgoda na zniesienie monopolu władzy ugrupowania komunistycznego symbolizowana była przez decyzje styczniowego plenum KC PZPR (Polska), lutowego plenum KC MSZMP (Węgry), czy postanowienia władz Słowenii (wrzesień 1989 roku). W pozostałych przypadkach stosowne decyzje zapadały już po wybuchu niezadowolenia społecznego (strajki, demonstracje, protesty uliczne) ${ }^{26}$.

Za przejaw konsolidacji przemian demokratycznych w omawianym regionie można przyjąć akces poszczególnych państw Europy Środkowej i Wschodniej do instytucji europejskich oraz paktów obronnych (np. NATO). Kryteria kopenhaskie, ustalone w czerwcu 1993 roku, wyznaczały wymogi stawiane przed państwami członkowskimi aspirującymi do Unii Europejskiej: można je pogrupować na kryteria polityczne oraz ekonomiczne. Kryteria polityczne obejmowały: istnienie instytucji gwarantujących stabilną demokrację przedstawicielską; rządy prawa; poszanowanie praw człowieka i obywatela; poszanowanie praw mniejszości. Kryteria ekonomiczne grupowały natomiast: funkcjonowanie gospodarki rynkowej mogącej sprostać konkurencji oraz wolnemu rynkowi; zdolność do przyjęcia acquis communautaire; oraz zdolność sprostania warunkom unii politycznej, gospodarczej i walutowej27.

W marcu 1999 roku do Sojuszu Północnoatlantyckiego przyjęto: Polskę, Węgry, Republikę Czeską. Z kolei w marcu 2004 roku kolejne państwa: Słowenię, Słowację, Rumunię, Bułgarię oraz trzy państwa bałtyckie: Litwę, Łotwę oraz Estonię. W 2009 roku członkami Sojuszu zostały oficjalnie Albania i Chorwacja, a w 2017 roku - Czarnogóra.

$\mathrm{Z}$ kolei integracja $\mathrm{z}$ instytucjami europejskimi oznaczała uznanie dla rezultatów zaawansowania reform polityczno-gospodarczych. W maju 2004 roku do UE zaproszono osiem państw postkomunistycznych: Polskę, Republikę Czeską, Słowację, Węgry, trzy

${ }^{25}$ Zob. S. Huntington, Trzecia fala transformacji...; J. Gorzkowski, W. Morawski, Jesień narodów, Warszawa 1991; P. Garde, Vie et mort de la Yougoslavie, Paris 1992 (wyd. chorwackie: Život i smrt Jugoslavije, Zagreb 1996).

${ }^{26}$ Zob. Cleavages, parties, and voters: studies from Bulgaria, the Czech Republic, Hungary, Poland, and Romania, ed. K. Lawson, A. Römmele and G. Karasimeonov, Westport; London: Praeger 1999.

${ }^{27}$ Zob. W. M. Góralski, Koncepcja ustrojowa i instytucjonalna II filara Unii Europejskiej, [w:] W. M. Góralski, Unia Europejska, Tom II. Gospodarka - Polityka - Współpraca, Wolters Kluwer Polska Sp. z o.o., Warszawa 2007, s. 12. 
państwa bałtyckie oraz Słowenię. W styczniu 2007 roku członkostwo uzyskały dwa państwa bałkańskie - Rumunia i Bułgaria, a w lipcu 2013 roku - Chorwacja. Przy wszystkich zastrzeżeniach można uznać ten moment za symboliczne zakończenie transformacji ustrojowej w omawianym regionie Starego Kontynentu. Nie oznacza to, rzecz jasna, osiagnięcia punktu kulminacyjnego transformacji. Kolejne zmiany w sferze politycznej, ustrojowej, społecznej czy gospodarczej należy raczej analizować pod kątem zachodzących procesów ewolucji systemu danego państwa, szczególnie w kontekście kształtowania się demokratycznej (partycypacyjnej) kultury politycznej ${ }^{28}$.

Reasumując, należy wskazać, iż tradycje ustrojowe (w tym państwowe) odgrywają spore znaczenie podczas procesu przeobrażeń ustrojowych w regionie Europy Środkowej i Wschodniej. Można pokusić się o wniosek wynikający z postawionej hipotezy, iż w państwach o dłuższej tradycji funkcjonowania demokratycznych instytucji przebieg procesów transformacyjnych przebiegał szybciej, nie napotykając na dodatkowe perturbacje wewnętrzne. Pozwalało to na wyodrębnienie podregionu zawierającego Europę Środkową w kontrze do państw bałkańskich i postradzieckich (republik słowiańskich). Na tym tle można również umiejscowić państwa bałtyckie (szczególnie Estonię), które uwzględniając niektóre czynniki społeczno-gospodarcze, osiagnęły lepsze rezultaty od państw wyszehradzkich (poziom korupcji, stopień zaufania społecznego, transparentność procedur).

\section{Bibliografia}

Agh A., The politics of Central Europe. London 1998.

Ajnenkiel A., Parlamentaryzm II Rzeczypospolitej, Warszawa 1975.

Ash T. G., Pomimo i wbrew - Eseje o Europie Środkowej, wyd. pol. Polonia, Londyn 1990.

Ash T. G., Wiosna obywateli: Rewolucja 1989: widziana w Warszawie, Budapeszcie, Berlinie i Pradze, wyd. pol. Polonia, Londyn 1990.

Batowski H., Podstawy kryzysu jugosłowiańskiego (konflikt chorwacko-serbski): odczyt wygłoszony na zebraniu publicznym PAU w Krakowie 16 listopada 1991 roku, Kraków 1993.

Besier G., Stokłosa K., Europa dyktatur: nowa historia XX wieku, Warszawa 2009.

Biagini A., Guida F., Pól wieku realnego socjalizmu: Europa Środkowowschodnia od II wojny światowej do upadku rzadów komunistycznych, Rzeszów 1998.

Borejsza J. W., Szkoty nienawiści: historia faszyzmów europejskich: 1919-1945, Wrocław 2000.

Brzeziński Z., Wielkie bankructwo. Narodziny i śmierć komunizmu w XX wieku, Paryż 1990.

Bujwid-Kurek E., Mikucka-Wójtowicz D., Transformacja ustroju politycznego wybranych państw Europy Środkowej i Poludniowo-Wschodniej, Kraków 2015.

Cet étrange post-communisme. Rupture et transition en Europe central et orientale, (ed.) G. Mink, J. Ch. Szurek, Paris 1992.

Communism in Eastern Europe, (red., współaut.) T. Rakowska-Harmstone, Manchester University Press 1979, 1984.

The consolidation of democracy in East-Central Europe, ed. K. Dawisha and B. Parrott, Cambridge University Press, Cambridge, New York 1997.

${ }^{28}$ Zob. P. Sekuła, Kultura polityczna a konsolidacja demokracji, Kraków 2009; Szanse i zagrożenia procesu konsolidacji systemu politycznego III Rzeczypospolitej Polskiej, red. J. Kuciński, Warszawa 2005; Democratization and Authoritarianism in Post-Communist Societies, (ed.) K. Dawisha, B. Parrott, Cambridge University Press 2011. 
Chodakiewicz M., Międzymorze, Warszawa 2016 (pierwodruk: Intermarium: the land between the Black and Baltic Seas, Transaction Publishers, New Brunswick 2012).

Chołaj H., Transformacja systemowa w Polsce: szkice teoretyczne, Lublin 1998.

Czapliński W., Zmiany terytorialne w Europie Środkowej i Wschodniej i ich skutki międzynarodowo-prawne: (1990-1992), Warszawa 1998.

Czas totalitaryzmu: stalinizm, faszyzm, nazizm i pokrewne systemy polityczne $w$ XX wieku, (red.) J. Szymoniczek, E. C. Król, Warszawa 2011.

Democratization and Authoritarianism in Post-Communist Societies, (ed.) K. Dawisha, B. Parrott, Cambridge University Press 2011.

Demokratyzacja w III Rzeczypospolitej, (red.) A. Antoszewski, Wrocław 2002.

Demokracje Europy Środkowo-Wschodniej w perspektywie porównawczej, (red.) A. Antoszewski, R. Herbut, Wrocław 1997.

Dyktatury w Europie Środkowo-Wschodniej, (red.) J. Żarnowski, Wrocław 1973.

Dudek A., Marszałkowski T., Walki uliczne w PRL 1956-1989, Kraków 1999.

Europa Środkowa a Bałkany; determinanty i ograniczenia przemian, (red.) J. Wojnicki, Warszawa 2016.

Europa Środkowa: wspólnota czy zbiorowość?, (red.) R. Zenderowski, Wrocław 2004.

Europa Środkowa jako przestrzeń spotkania: na szlakach tradycji kultury, (red.) K. Święcicki, Gniezno 2012.

Europa Środkowa $i$ Wschodnia $w$ XX wieku: studia ofiarowane Wiesławowi Balcerkowi $w 70$ rocznice urodzin, (red.) A. Koryn, P. Łossowski, Warszawa-Lowicz 2004.

Europa Środkowo-Wschodnia wobec wyzwań integracyjnych, (red.) A. Stępień-Kuczyńska, Łódź 2003.

Europa Środkowa i Wschodnia w 19 i 20 wieku, (red.) E. Wiśniewski, Łódź 2005.

Fukuyama F., Koniec historii, Poznań 1996 [pierwodruk: Koniec historii?, [w:] Czy koniec historii? Konfrontacje 13, New York, Warszawa 1991, Idee, Wydawnictwo Pomost, s. 7-36 (thumaczenie eseju z „The National Interest”, nr 16, lato 1989)].

Garde P., Vie et mort de la Yougoslavie, Paris 1992 (wyd. chorwackie: Život i smrt Jugoslavije, Zagreb 1996).

Gwiżdż A., Burżuazyjno-obszarnicza konstytucja z 1921 roku w praktyce, Warszawa 1956.

Historia Europy Środkowowschodniej, tom I, (red.) J. Kłoczowski, Lublin 2000.

Holzer J., Komunizm w Europie: dzieje ruchu i systemu władzy, Warszawa 2000.

Huntington S., Zderzenie cywilizacji i nowy kształt ladu światowego, Warszawa 1997 (pierwodruk: w The Clash of Civilizations?, „Foreign Affairs”, lato 1993, vol. 72).

Kamiński Ł., Malkiewicz A., Ruchniewicz K., Opór społeczny w Europie Środkowej w latach 1948-1953 na przykładzie Polski, NRD i Czechostowacji: wstęny raport z badań, Wrocław 2004.

Kłoczowski J., Europa Środkowowschodnia w historiografii krajów regionu, Lublin 1993.

Kofman J., Roszkowski W., Transformacja i postkomunizm, Warszawa 1999.

Komarnicki W., Polskie prawo polityczne, Warszawa 1922 [reprint z 2008].

Mizerski E., Geneza i rozpad ustroju federalnego byłych socjalistycznych państw europejskich, Toruń 1996.

Modernizacja w Rosji, „Studia Politologiczne”, 2016, vol. 40.

Morlino L., Democratic Establishment: A Dimensional Analysis, [in:] Comparing New Democracies. Transition and Consolidation in Mediterranean Europe in the Southern cone, (ed.) E. Baloyra, London 1987.

New Europe. The Impact of the First Decade, vol. 2: Variations on the Pattern, (ed.) P. Dutkiewicz, T. Rakowska-Harmstone, Warsaw 2006.

Nowe konstytucje, (red.) J. Makowski, Warszawa 1925. 
Państwa komunistyczne u progu lat siedemdziesiatych, (red.) T. Rakowska-Harmston, A. Bromke, Londyn 1973.

Przeworski A., Democracy and the Market; Political and Economic Reforms in Eastern Europe and Latin America, Cambridge University Press, New York 1991.

Przewroty i zamachy stanu. Europa 1918-1939, (red.) A. Garlicki, Warszawa 1981.

Rakowska-Harmstone T., Disintegration and Re-definition of East Europe, Warsaw 1992.

Reform and transformation in Eastern Europe, (red.) W. Łukowski, K. A. Wojtaszczyk, Warsaw 1996.

Roszkowski W., East Central Europe. A Concise History, Warsaw 2015.

Roszkowski W., Pótwiecze: historia polityczna świata, Warszawa 2005.

Rozpad ZSRR i jego konsekwencje dla Europy i świata, (red.) J. Diec, Kraków 2011.

Sekuła P., Kultura polityczna a konsolidacja demokracji, Kraków 2009.

Sobolewski M., Od drugiego cesarstwa do piatej republiki: z dziejów politycznych Francji 1870-1958, Warszawa 1963.

Staniszkis J., Postkomunizm. Próba opisu, Gdańsk 2001.

Starzyński S., Współczesny ustrój prawno-polityczny Polski i innych państw słowiańskich, Lwów 1928 [reprint z 2010].

Szanse i zagrożenia procesu konsolidacji systemu politycznego III Rzeczypospolitej Polskiej, (red.) J. Kuciński, Warszawa 2005.

Tomaszewski J., Europa Środkowo-Wschodnia 1944-1968: powstanie, ewolucja i kryzys realnego socjalizmu, Warszawa 1992.

Transformacja, elity, społeczeństwo, (red.) M. Jarosz, Warszawa 2007.

Transformacja, integracja, globalizacja, (red.) S. Miklaszewski, Kraków 2003.

Transformacja systemowa w krajach Europy Środkowej, Wschodniej i Poludniowej 1989-2002: wybrane problemy, (red.) T. Godlewski, A, Koseski, K. A. Wojtaszczyk, Bydgoszcz-Pułtusk 2003.

Transformacja systemowa w Polsce: wybrane aspekty, (red.) K. Łabędź, Kraków 2012.

Transformacja systemowa $w$ Polsce i krajach postkomunistycznych, (red.) M. Chałubiński, Pułtusk 2006.

Transformacja ustrojowa państw Europy Środkowej i Wschodniej, (red.) E. Zieliński, Warszawa 1996.

Transformationsprozesse in Polen: aus der Reihe - Deutschland und Polen in Europa, (ed.) K. A. Wojtaszczyk, Warschau 1993.

Wandycz P. S., Cena wolności. Historia Europy Środkowowschodniej od średniowiecza do wspótczesności, Kraków 2003.

Wiatr J., Europa pokomunistyczna: przemiany państw i społeczeństw po 1989 roku, Warszawa 2006.

Winiecki J., Transformacja postkomunistyczna: studium przypadku zmian, Warszawa 2012.

Wnuk-Lipiński E., Demokratyczna rekonstrukcja. Z socjologii radykalnej zmiany, Warszawa 1996.

Wnuk-Lipiński E., Rozpad połowiczy. Szkice z socjologii transformacji ustrojowej, Warszawa 1991.

Wojnicki J., Trudna droga do demokracji. Europa Środkowo-Wschodnia po 1989 roku, Warszawa 2002.

Jacek Wojnicki, profesor nauk społecznych, pracownik naukowo-dydaktyczny Uniwersytetu Warszawskiego, Wydział Nauk Politycznych i Studiów Międzynarodowych, kierownik Katedry Systemów Politycznych. Jego zainteresowania badawcze obejmują systemy polityczne oraz administracyjne państw Europy Środkowej i Bałkanów. 